\title{
The Effect of Timing of Cord Clamping On Neonatal Venous Haematocrite Values
}

\author{
Dr. Parvati Devi
}

\section{Introduction}

When a newborn is born there is lot of difference in opinion, when to clamp the cord,is there any beneficial or harmful effects of clamping the cord early or visa versa. undertaken.

Hence to know the outcome of delayed cord clamping and early cord clamping this study was

Haematocrit/packed cell volume (PCV).

Haematocrit is the volume of red cells expressed as a percentage of volume of whole blood in the sample. The venous haematocrit is almost same as that obtained from a skin puncture. Dried heparin, EDTA or double oxalate are satisfactory anticoagulants that can be used to measure haematocrit.

Normal values of haematocrit

$\begin{array}{ll}\text { In New born } & 42-65 \%(51.5 \pm 4.5 \%) \\ \text { At } 3 \text { months } & 29-54 \% \\ \text { emale } & 37-47 \% \\ \text { ale } & 40-54 \%\end{array}$

Adult female
Adult male

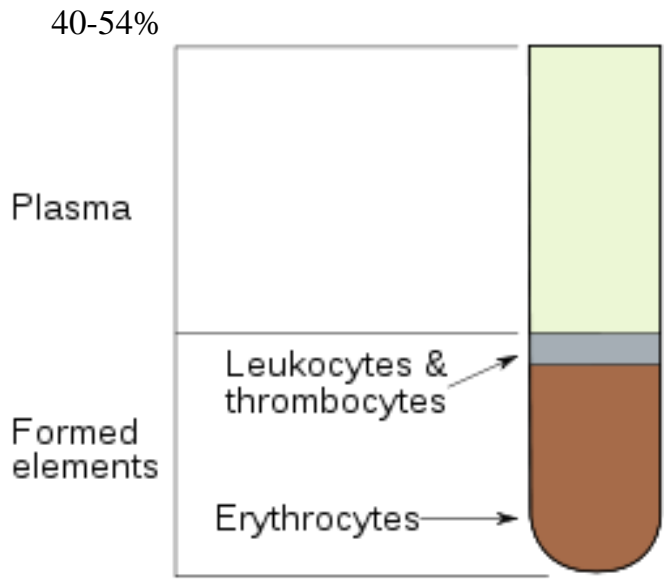

Fig 1. Wintrobes tube

The term "haematocrit was coined in 1903. Its roots stem from the Greek word haemo-means blood, and keiten-means judge, meaning to gauge or judge the blood. The packed cell volume (PCV) can be determined by centrifuging heparinized blood in a capillary tube (also known as a microhaematocrit tube) at 10000 RPM for five minutes. This separates the blood into 2 layers. Upper layer is occupied by plasma and lower layer occupied by red blood cells. The volume of packed red blood cells divided by the total volume of the blood sample gives the PCV. With modern lab equipment, the haematocrit is calculated by an automated analyzer. Haematocrit is determined by multiplying the red cell count by the mean cell volume. The haematocrit is slightly more accurate as the PCV includes small amount of blood plasma trapped between the red blood cells. An estimated haematocrit as a percentage may be derived by tripling the haemoglobins concentration.

\section{Haematocrit is measured using \\ 1. Wintrobe's tube \\ 2. Microhaematocrit capillaries.}

\section{Wintrobes Tube}

Fill the Wintrobe's tub'e till the 100 mark on top with a Pasteur pipette ensuring that there are no airbubbles in the blood column. Centrifuge this tube for 15 minutes at $3500 \mathrm{rpm}$ (or longer at lower speeds) until sedimentation is complete. After centrifuging, the blood is separated into 3 layers, a column of red blood cells at the bottom, a narrow middle layer-buffy coat of WBCs and platelets and the top most fluid column of plasma. The percentage of the height of the blood occupied by packed red cells constitutes the haematocrit. Roughly, the haematocrit value is three times the hemoglobin concentration. 


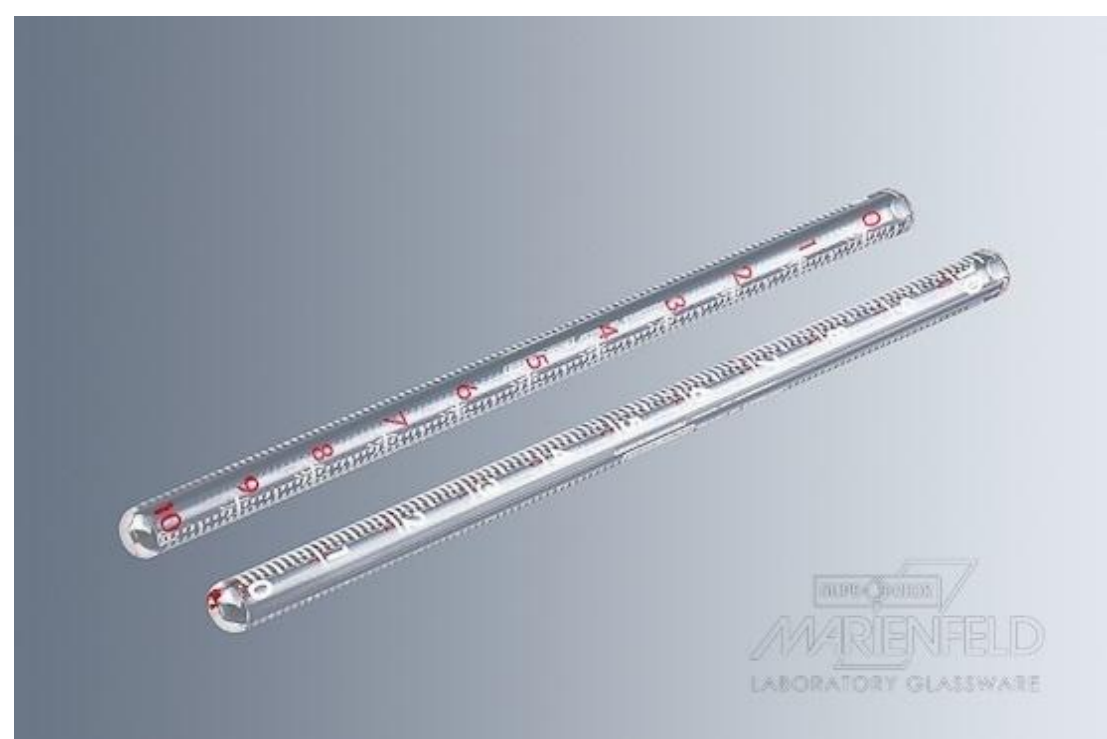

Fig 2. Wintrobes tube.

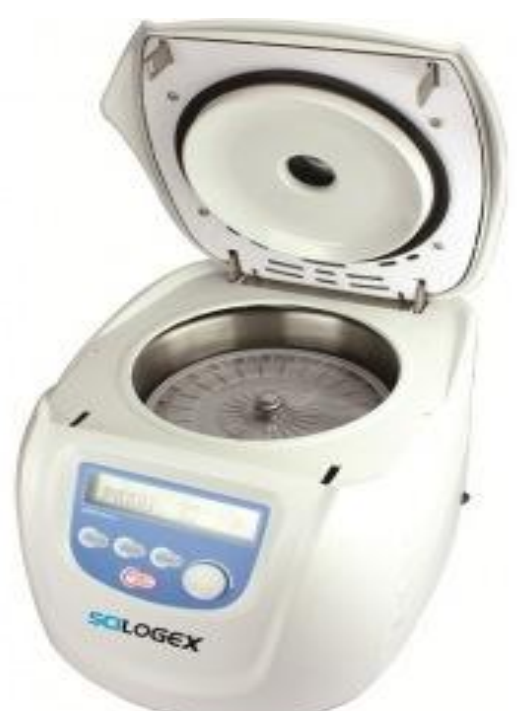

Fig 3. Microhaematocrit

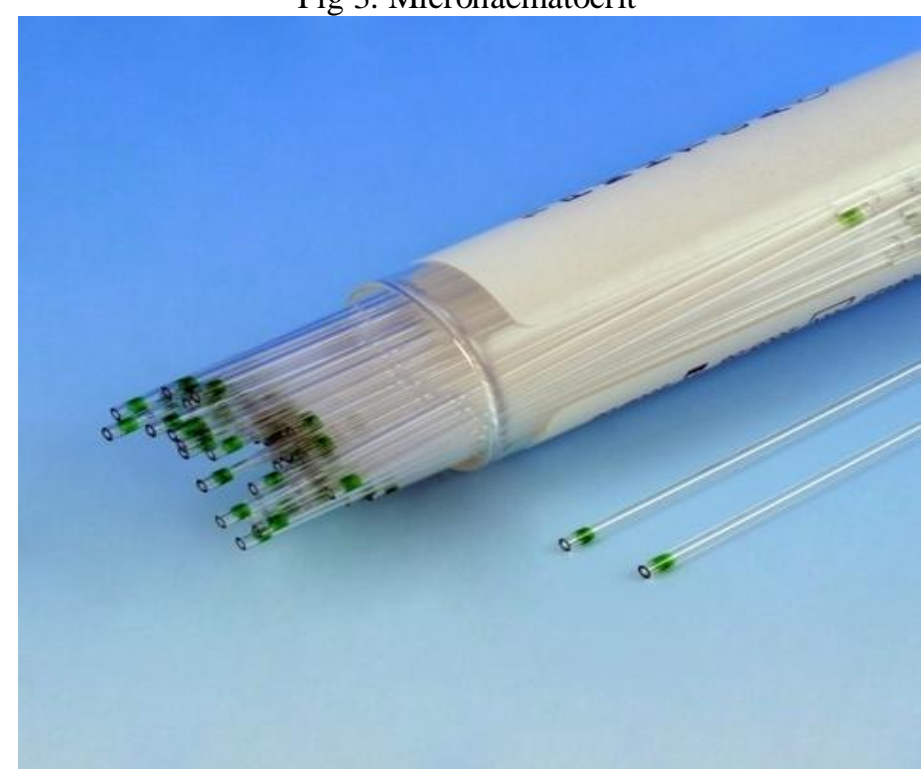

Fig 4. Capillary tubes 
Microhaematocrit method is in common use in most well-equipped laboratories. Capillary tubes coated with anticoagulant can be filled with blood obtained from finger puncture or from a venipuncture or with blood already anticoagulated. One end of the filled capillary tube is sealed with sealing wax (e.g. Plasticine) or the empty end is sealed by heating the tube. The sealed tube is centrifuged for 3 minutes in a special high-speed centrifuge. By reading the packed cell height and the total height of the entire specimen, the haematocrit can be determined. Special reading devices are available on the instrument.

For example, if the red cells are of normal size (normocytic), and the red cell count is 5 million, the haematocrit is about $45 \%$.

For men-haematocrit range from $42-52 \%$, average $47 \%$

For women-haematocrit range from $37-47 \%$, average $42 \%$.

For newborn-haematocrit range from $42-65 \%$

\section{Interpretation}

In anaemia there is reduced haematocrit ,for men less then $42 \%$,and for women less then $37 \%$. In polycythemia there is raised haematocrit, that is more then $65 \%$.

\section{Coulter Principle Is Used To Measure Haematocrit.}

The Coulter principle states that particles pulled through an orifice, concurrent with an electrical current, produce a change in impedance that is proportional to the size of the particle traversing the orifice. The Coulter principle was named after its inventor, Wallace H Coulter.

Wallace was an electrical engineer by training with a passion for radio technology. During the second world war, Wallace joined the US Navy. While working on a technique to detect submarines using sonar, he frequently detected large echos where no submarines were operating. In an attempt to determine the source, Wallace lowered a series of small bottles with remote trap doors to various depths. The bottles were constructed such that the remote door could be opened and shut at predetermined depths, filling the bottle with seawater from that depth. The source of the false echo turned out to be high concentrations of plankton (mass of tiny animals and plants that live in the surface of the sea). In order to count the number of plankton cells per milliliter of seawater accurately and reproducibly, Wallace created a device that would become the basis for the Coulter principle.

The device consisted of a dual chambered container whose two sides were separated by a thin membrane. A small hole in the membrane called an aperture was the only connection between the two chambers. Electrodes from a battery were placed in the chambers, positive on one side and negative on the other. An ohm meter was connected to the circuit so as to measure the resistance to the flow of current (impedance) from one electrode, through the orifice, and to the other electrode. Both chambers were filled with seawater from the trap bottles. Then one of the two chambers was partially drained, forcing seawater to flow from the opposite chamber, through the orifice to balance the level of liquid in the two sides. As the seawater passed through the orifice so did the plankton cells, which created momentary changes in impedance that were seen on the ohm meter. By counting the number of impedance pulses per unit of seawater, Wallace's device was able to count the number of plankton particles.

This technology found commercial success in the medical industry where it revolutionized the science of hematology. Red blood cells, white blood cells and platelets make up the majority of the formed elements in the blood. The average salinity of human blood is very close to that of seawater, and mixture of salt (NaCI) and water with the same salinity as seawater is said to be isotonic with whole blood. When whole anti-coagulated human blood is diluted with isotonic saline, the Coulter principle can be applied to count and size the various cells that make up whole blood. The first commercial application of the Coulter principle to hematology came in 1954 with the release of the Coulter Model A (developed by Wallace and brother Joseph R. Coulter). Within a decade, literally every hospital laboratory in the United States had a Coulter Counter, and today every modern hematology analyzer depends in some way on the Coulter principle. ${ }^{12}$ 


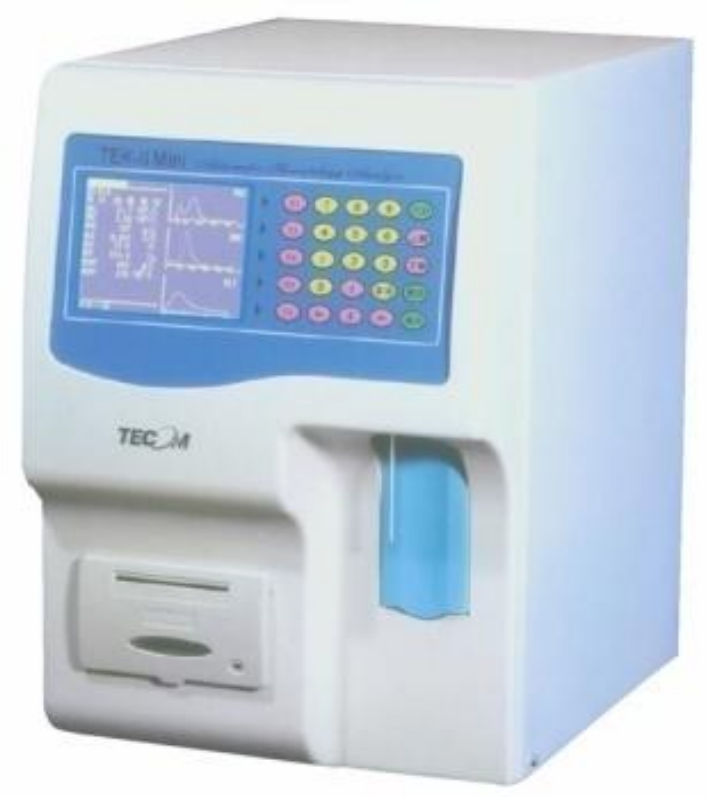

Fig 5.Coulter automated analyser

\section{Aims And Objectives Of Study}

The purpose of this randomized control trial is to determine the effect of timing of cord clamping on neonatal venous haematocrit values.

\section{Review Of Literature}

In some studies ${ }^{3}$ done by Jose M Ceriani Cernades MD, it was observed that delayed cord clamping could contribute to preventing iron deficiency anaemia in first year of life. The reason for this effect is based on the fact that after birth the newborn is delivered with a placental transfusion of about $80 \mathrm{ml}$ of extra blood at 1 min after birth and $100 \mathrm{ml}$ of extra blood at $3 \mathrm{~min}$ after birth. This volume will supply 40 to $50 \mathrm{mg} / \mathrm{kg}$ of extra iron to the $75 \mathrm{mg} / \mathrm{kg}$ of body iron that newborn term infant have, reaching a total of 115 to $120 \mathrm{mg} / \mathrm{kg}$, which might prevent iron deficiency anaemia in the first year of life. Iron deficiency early in life may have pronounced central nervous system effects such as cognitive impairment, delayed milestones, learning difficulties. Iron deficiency also the main cause of anaemia, which is one of the most common condition in childhood, especially in developing countries like India. The public health magnitude of anaemia amongst children in India has been brought to the force by the recent NFHs survey. ${ }^{4}$ Which has recorded that almost 70\% of infants between 6-11 months are anaemic. It has also demonstrated a strong association between maternal haemoglobin levels and prevalence of anaemia amongst their childrens. Iron stores at birth is a major factor influencing growth and the occurrence of iron deficiency anaemia during infancy. These stores are determined by the transplacental iron transferred to the foetus and the blood transferred from the placenta at delivery. The iron content of human milk is low, and also the absorption of iron is also poor during 4 to 10 months of age, thus making this period vulnerable to iron deficiency anaemia. The recent NFHs survey has reported very high prevalence of anaemia both in mothers and their childrens in India, with almost a quarter of children of severely anaemic mothers being also severely anemic. Iron stores at birth correlates with iron stores at 6-12 months. Studies have observed that infants of mothers with moderate to severe anaemia has significantly lower cord serum ferritin level and hence lower iron stores at birth. Iron stores at birth is an important determinant of anaemia in infancy. Delayed clamping of cord at birth has been suggested as a possible strategy to prevent anaemia in infants between 4-11 months of age. At two months after delivery the group with delayed cord clamping has significantly high haemoglobin and haematocrit.Thus it appears that infants born to anaemic mother benefit more than those born to non-anaemic mothers from the additional iron they derive from the blood passed from the placenta as a result of delayed clamping. These benefits appears to outweigh any risk that may result from delayed clamping (such as polycythemia or volume overload). More of the trials have demonstrated increase risk of these potential side effects. There is a need to incorporate delayed clamping as a component of routine active labour management this strategy can impact upon the existing high prevalence of anaemia in infancy and early childhood. ${ }^{5,6}$

When cord clamping was delayed for at least $2 \mathrm{~min}$, benefits over 2 to 6 months include increased haematocrit, raised serum ferritin levels, and a clinically important reduction in risk of anaemia. Neonates with late clamping were at risk of experiencing asymptomatic polycythemia. Previous research has suggested that early clamping of cord (within 5 to 10 secs) compared with late clamping, result in decease to the neonate of 20 
to $40 \mathrm{ml}$ of blood per $\mathrm{kg}$ of body weight, which would provide the equivalent of 30 to $35 \mathrm{mg}$ of iron. It has been argued that early cord clamping puts the newborn at increased risk of hypovolemia as well as of several blood disorders and type 2 diabetes, as a consequence of loss of hematopoietic stem cells. Early cord clamping has been postulated as a major cause of anaemia in infancy, that held some investigators to recommend late clamping as a low-cost intervention to reduce anaemia in the first 6 months of life. Other believe that the increase in blood volume to the neonate resulting from delay in clamping may be harmful and could result in overloading the neonate, thus increasing the likelihood of respiratory distress, neonatal jaundice, and polycythemia. $^{7}$

"If delayed cord clamping is adopted as a means to reduce the incidence of respiratory distress syndrome in premature births, there will be an accompanying augmentation of hyperbilirubinemia to deal with". True, hyperbilirubinemia might be prevented in premature and medicated infants by early clamping; however, in a normal delivery of full-term, un-medicated infant, there are untold advantages to delayed cord clamping until after the placenta has delivered itself. ${ }^{8}$

In recent Cochrane review of cord clamping in preterm population, late clamping is potential benefit in terms of decrease need of blood transfusion and lower risk of intraventricular hemorrhage.Iron deficiency anaemia is a serious health problem that affects the physical and cognitive development of children, therefore it is important to develop cost effective interventions (i.e. delayed cord clamping) to improve the hematologic status to the millions of children affected by this conditions worldwide. ${ }^{9}$

No significant differences between early and late cord clamping were seen for postpartum hemorrhage. Delaying cord clamping until the pulsation stops increases the red cell mass in term infants. It is safe and simple and low cost delivery procedure that should be incorporated in integrated programmes aimed at reducing iron deficiency anaemia in infants in developing countries. No significant differences were found in clinical jaundice. These infants in delayed cord clamping group had polycythemia without symptoms, for which no partial exchange transfusion was necessary. ${ }^{10}$

Clamping the cord in seconds after birth cuts off the blood flow from mother to baby, while not necessarily harmful, the common practice in delivery room potentially robs newborns of those last precious minutes of cord blood. The researchers said, cord blood contains stem cells that have regenerative properties and can grow into different types of cells. Delayed clamping for an extra minute or two may help prevent anaemia in full term infants according to the study cited by researchers. Studies on preterm infants have found delayed clamping the cord for $30 \mathrm{sec}$, or more reduced the incidence of anaemia, intraventricular hemorrhage, late onset sepsis and decrease need for blood transfusions. The clamping of umbilical cord of newborns in full term pregnancies two minutes after birth shown to increase a haematocrit. Thus the study shows that early clamping is not justified. This study also found that the partial pressure of oxygen in the umbilical artery of the late clamped newborn babies is high there by there was a lesser need of oxygen therapy after birth. Other advantages of delayed cord clamping are, reduced concentration of triacylglyceride in umbilical veins of delayed clamped group. ${ }^{11,12}$

\section{Outcome measures:}

The primary outcome measures was the neonatal venous haematocrit values found to be more in delayed clamped group.

Secondary outcome measures

- Jaundice

- Admission to NICU(for phototherapy)

- Newborn length of hospital stay

- Any neonatal disease that occurred between birth and 1 month of age

All these secondary outcomes are not significant. ${ }^{13}$

Delayed cord clamping for at least $3 \mathrm{~min}$ in healthy newborn improves their iron level at 4 months. ${ }^{14,15,16,17}$

Delayed cord clamping is not linked to neonatal jaundice or other adverse health effects and should be standard care after uncomplicated pregnancy. ${ }^{18,19,20}$

Cord blood contains many valuable stem cells, making this transfer of stem cells a process that might be, considered 'the original stem cell transplant. ${ }^{21,22,23,24}$

Delayed cord clamping is beneficial in extremely low birth weight neonates, and in preterm neonates in preventing intraventricular hemorrhage, late onset sepsis, increases the immunological tolerance and also decreased need for blood transfusion. $25,26,27,28,29,30$

Delayed cord clamping also has a role in postnatal cerebral oxygenation in preterm neonates. ${ }^{31,32,33,34,35,36,37}$ 


\section{Materials And Methods:}

Source of data - Neonates with Full term normal delivery in JSS Hospital-from November 2010 to July 2012.

Method collection of data: Is by randomized control trial.

Study design - Randomized control trial.

Sample Size: 100 neonates in each group i.e. control and study group

Inclusion criteria:

Healthy women with uneventful full term, cephalic presentation, singleton pregnancy, vaginal delivery at JSS

Hospital from November 2010 to July 2012.

Exclusion criteria:

Patients with following conditions are excluded,

Preeclampsia.

Eclampsia.

Chronic hypertension.

$\mathrm{Rh}$ negative pregnancy.

Moderate to severe anaemic mothers.

Meconium stained amniotic fluid.

Fetal anomalies.

Infants requiring operative delivery by forceps and vacuum.

Group 1

Study group

New born who's cord is clamped at cessation of pulsation.

Group 2 - control group

New born who's cord is clamped immediately after birth.

Blood of neonate is drawn for

PCV (haematocrit) at 18-24 hours after birth and at 1 and half months of life.

\section{Statistical methods applied}

Frequencies

The Frequencies procedure provides statistics and graphical displays that are useful for describing many types of variables. The Frequencies procedure is a good place to start looking at your data.

\section{Crosstabs (Contingency coefficient test)}

The Crosstabs procedure forms two-way and multiway tables and provides a variety of tests and measures of association for two-way tables. The structure of the table and whether categories are ordered determine what test or measure to use.

Independent-Samples T Test

The Independent-Samples T Test procedure compares means for two groups of cases. Ideally, for this test, the subjects should be randomly assigned to two groups, so that any difference in response is due to the treatment (or lack of treatment) and not to other factors.

All the statistical calculations were done through SPSS 16.0 (2007) for windows.

\section{Observations And Results}

Neonates of full term normal delivery at J.S.S Hospital from November 2010 to July 2012 were included in the study.

Variables included are,

Age.

Gravida.

Duration of pregnancy.

Maternal haematocrit.

Neonatal haematocrit.

Neonatal birth weight.

Neonatal sex.

Neonatal birth weight and development of jaundice.

Neonatal birth weight and development of jaundice for which phototherapy was needed

Length of hospital stay.

Follow up at one and half months of life. 
Table 1. Age distribution of women

\begin{tabular}{|c|c|c|c|c|c|}
\hline & \multirow[b]{2}{*}{ Variable } & & \multicolumn{2}{|c|}{ GROUP } & \multirow[b]{2}{*}{ Total } \\
\hline & & & Case & Ctrl & \\
\hline \multirow{8}{*}{$\begin{array}{l}\text { AGE in } \\
\text { years. }\end{array}$} & \multirow[t]{2}{*}{$18-20$} & frequency & 30 & 29 & 59 \\
\hline & & $\%$ & $30.0 \%$ & $29.0 \%$ & $29.5 \%$ \\
\hline & \multirow[t]{2}{*}{$21-25$} & frequency & 49 & 48 & 97 \\
\hline & & $\%$ & $49.0 \%$ & $48.0 \%$ & $48.5 \%$ \\
\hline & \multirow[t]{2}{*}{$26-30$} & frequency & 17 & 19 & 36 \\
\hline & & $\%$ & $17.0 \%$ & $19.0 \%$ & $18.0 \%$ \\
\hline & \multirow[t]{2}{*}{$31-35$} & frequency & 4 & 4 & 8 \\
\hline & & $\%$ & $4.0 \%$ & $4.0 \%$ & $4.0 \%$ \\
\hline \multirow{2}{*}{\multicolumn{2}{|c|}{ Total }} & Frequency & 100 & 100 & 200 \\
\hline & & $\%$ & $100.0 \%$ & $100.0 \%$ & $100.0 \%$ \\
\hline
\end{tabular}

$\mathrm{P}=0.987$ (Not significant)

The above table shows the age distribution of 200 women, who are included in the study in between the ages 18-35 years.100 women in each group. They are divided into 4 sub groups, with maximum number of women belonging to age group between 21-25 years in both case and control group.

\section{Graph 1. Age distribution of women}

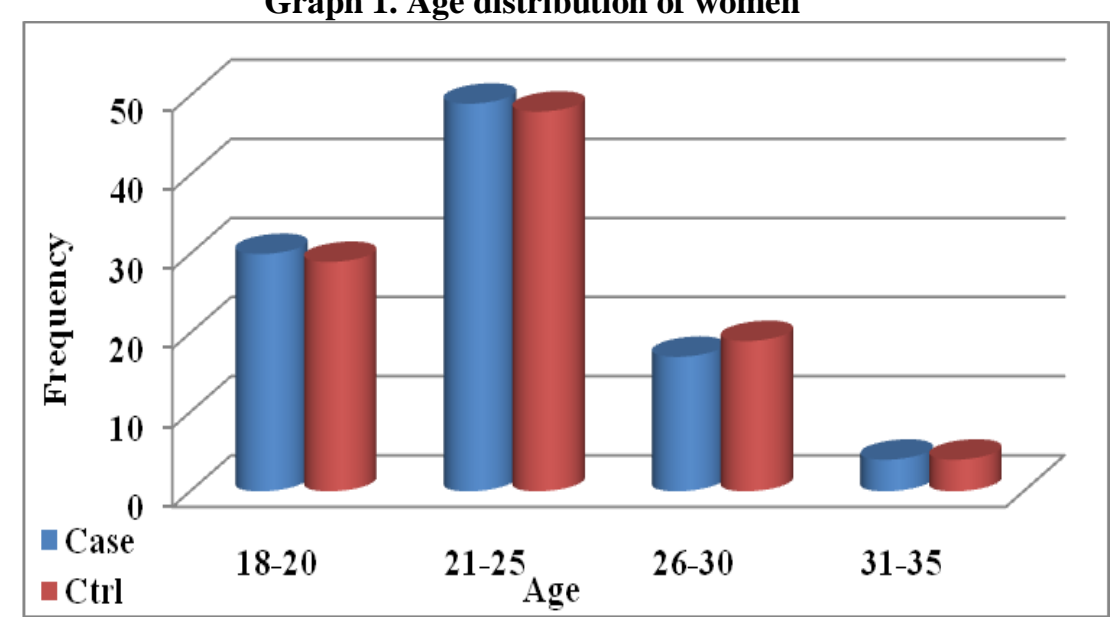

Table 2. Gravida

\begin{tabular}{|c|c|c|c|c|c|}
\hline & & & \multicolumn{2}{|c|}{ GROUP } & \multirow[b]{2}{*}{ Total } \\
\hline \multicolumn{2}{|c|}{ Variables } & & Case & Ctrl & \\
\hline \multirow[t]{4}{*}{ GRAVIDA } & \multirow[t]{2}{*}{ Primi } & Frequency & 58 & 55 & 113 \\
\hline & & $\%$ & $58.0 \%$ & $55.0 \%$ & $56.5 \%$ \\
\hline & \multirow[t]{2}{*}{ Multi } & Frequency & 42 & 45 & 87 \\
\hline & & $\%$ & $42.0 \%$ & $45.0 \%$ & $43.5 \%$ \\
\hline \multirow{2}{*}{\multicolumn{2}{|c|}{ Total }} & Frequency & 100 & 100 & 200 \\
\hline & & $\%$ & $100.0 \%$ & $100.0 \%$ & $100.0 \%$ \\
\hline
\end{tabular}

$\mathrm{P}=0.669$ (Not significant)

- The above table shows the gravida status of 200 women 100 women in each group, and the maximum women are primigravida,58\% were primigravida in cases and 55\% were primigravida in controls. And $42 \%$ were multigravida in cases and $45 \%$ in control. 


\section{Graph 2. Gravida}

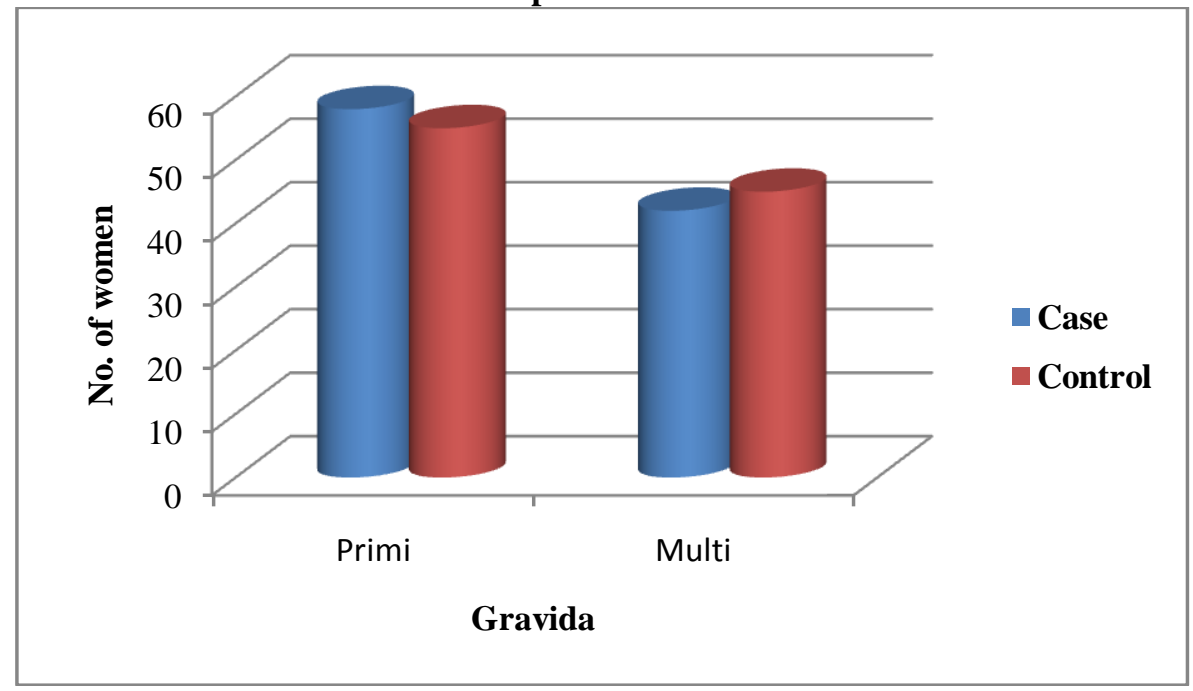

Table 3. Gestational age of women.

\begin{tabular}{|c|c|c|c|c|c|}
\hline \multirow{2}{*}{\multicolumn{2}{|c|}{ Variable }} & & \multicolumn{2}{|c|}{ GROUP } & \multirow[b]{2}{*}{ Total } \\
\hline & & & Case & Ctrl & \\
\hline \multirow[t]{4}{*}{ GA in weeks } & \multirow[t]{2}{*}{$37-39$} & Frequency & 64 & 66 & 130 \\
\hline & & $\%$ & $64.0 \%$ & $66.0 \%$ & $65.0 \%$ \\
\hline & \multirow[t]{2}{*}{$40-42$} & Frequency & 36 & 34 & 70 \\
\hline & & $\%$ & $36.0 \%$ & $34.0 \%$ & $35.0 \%$ \\
\hline \multirow{2}{*}{\multicolumn{2}{|c|}{ Total }} & Frequency & 100 & 100 & 200 \\
\hline & & $\%$ & $100.0 \%$ & $100.0 \%$ & $100.0 \%$ \\
\hline
\end{tabular}

$\mathrm{P}=0.767$ (Not significant)

- The above table shows duration of amenorrhoea in weeks. Maximum women are in gestational age between 37 to 39 weeks in both groups.64\% women were in cases, and $66 \%$ women were in control.

Graph 3. Gestational age of women.

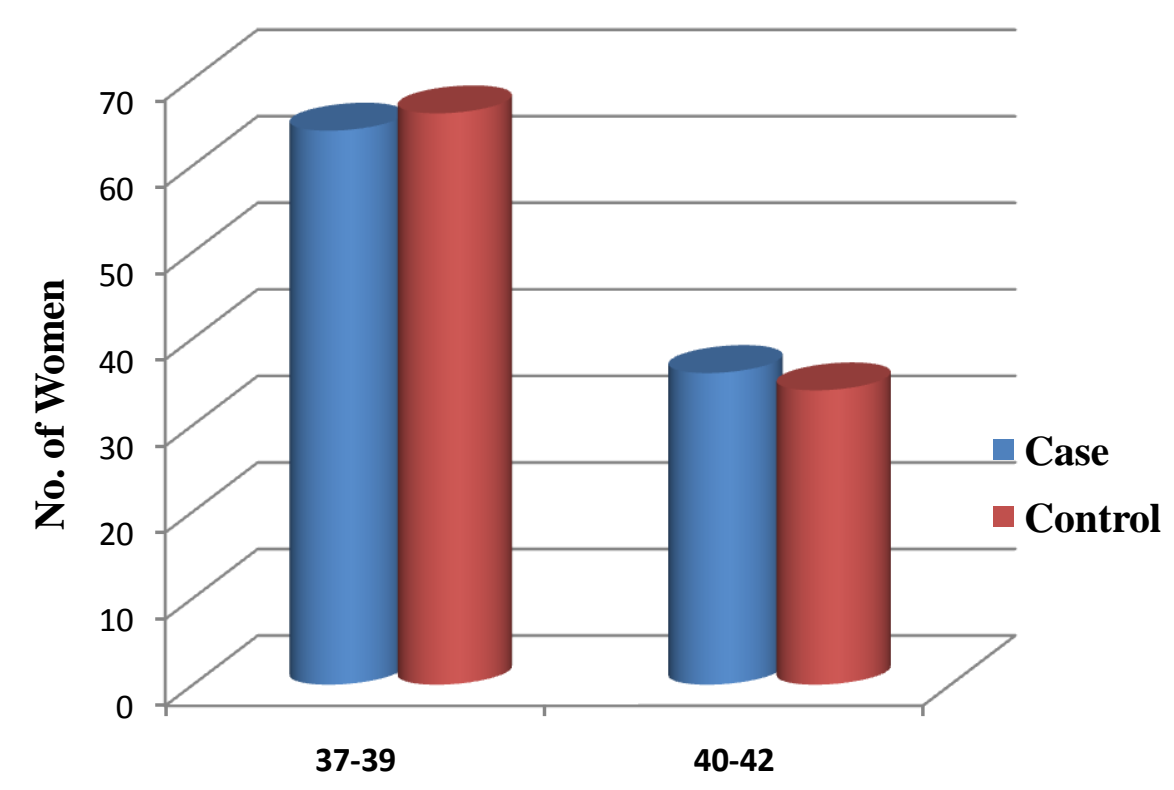

Gestational age (in weeks)

Table 4. Birth weight of newborns in kgs 
The Effect of Timing of Cord Clamping On Neonatal Venous Haematocrite Values

\begin{tabular}{|c|c|c|c|c|c|}
\hline & & & \multicolumn{2}{|c|}{ GROUP } & \multirow[b]{2}{*}{ Total } \\
\hline \multicolumn{2}{|c|}{ Variable } & & Case & Ctrl & \\
\hline \multirow{8}{*}{$\begin{array}{c}\text { B_WT in } \\
\text { kgs }\end{array}$} & \multirow[t]{2}{*}{$<2.5$} & Frequency & 5 & 8 & 13 \\
\hline & & $\%$ & $5.0 \%$ & $8.0 \%$ & $6.5 \%$ \\
\hline & \multirow[t]{2}{*}{$2.5-3$} & Frequency & 56 & 58 & 114 \\
\hline & & $\%$ & $56.0 \%$ & $58.0 \%$ & $57.0 \%$ \\
\hline & \multirow[t]{2}{*}{$3.1-3.5$} & Frequency & 32 & 25 & 57 \\
\hline & & $\%$ & $32.0 \%$ & $25.0 \%$ & $28.5 \%$ \\
\hline & \multirow[t]{2}{*}{$3.5+$} & Frequency & 7 & 9 & 16 \\
\hline & & $\%$ & $7.0 \%$ & $9.0 \%$ & $8.0 \%$ \\
\hline \multirow{2}{*}{\multicolumn{2}{|c|}{ Total }} & Frequency & 100 & 100 & 200 \\
\hline & & $\%$ & $100.0 \%$ & $100.0 \%$ & $100.0 \%$ \\
\hline
\end{tabular}

$\mathrm{P}=0.607$ (Not significant)

The above table shows the birth weight of 200 newborns with mean range varying from $2.5 \mathrm{~kg}$ to $3 \mathrm{~kg}, 56 \%$ of newborns in cases and $58 \%$ of newborns in control are in this range

\section{Graph 4. Birth weight of newborns}

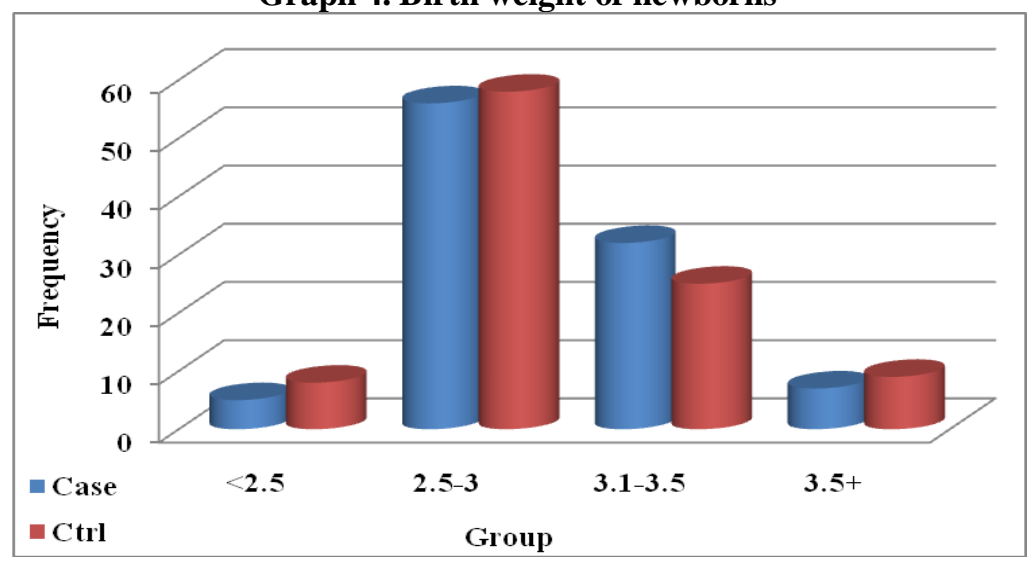

Table 5. Maternal PCV

\begin{tabular}{|c|c|c|c|c|c|}
\hline \multirow{2}{*}{\multicolumn{2}{|c|}{ Variables }} & & \multicolumn{2}{|c|}{ GROUP } & \multirow[b]{2}{*}{ Total } \\
\hline & & & Case & Ctrl & \\
\hline \multirow[t]{6}{*}{ MATPCV in \% } & \multirow[t]{2}{*}{$30-35.9$} & Frequency & 69 & 61 & 130 \\
\hline & & $\%$ & $69.0 \%$ & $61.0 \%$ & $65.0 \%$ \\
\hline & \multirow[t]{2}{*}{$36-41.9$} & Frequency & 30 & 39 & 69 \\
\hline & & $\%$ & $30.0 \%$ & $39.0 \%$ & $34.5 \%$ \\
\hline & \multirow[t]{2}{*}{$41.9+$} & Frequency & 1 & 0 & 1 \\
\hline & & $\%$ & $1.0 \%$ & $.0 \%$ & $.5 \%$ \\
\hline \multirow{2}{*}{\multicolumn{2}{|c|}{ Total }} & Frequency & 100 & 100 & 200 \\
\hline & & $\%$ & $100.0 \%$ & $100.0 \%$ & $100.0 \%$ \\
\hline
\end{tabular}

$\mathrm{P}=0.264$ (Not significant)

The above table shows distribution of PCV in 200 women, 100 women in each group, maximum women had a $\mathrm{PCV}$ in a range varying from $30 \%$ to $35.9 \%$ in both the group.

$69 \%$ of women in cases and $61.1 \%$ of women in control belongs to this range. 


\section{Graph 5. Distribution of maternal PCV}

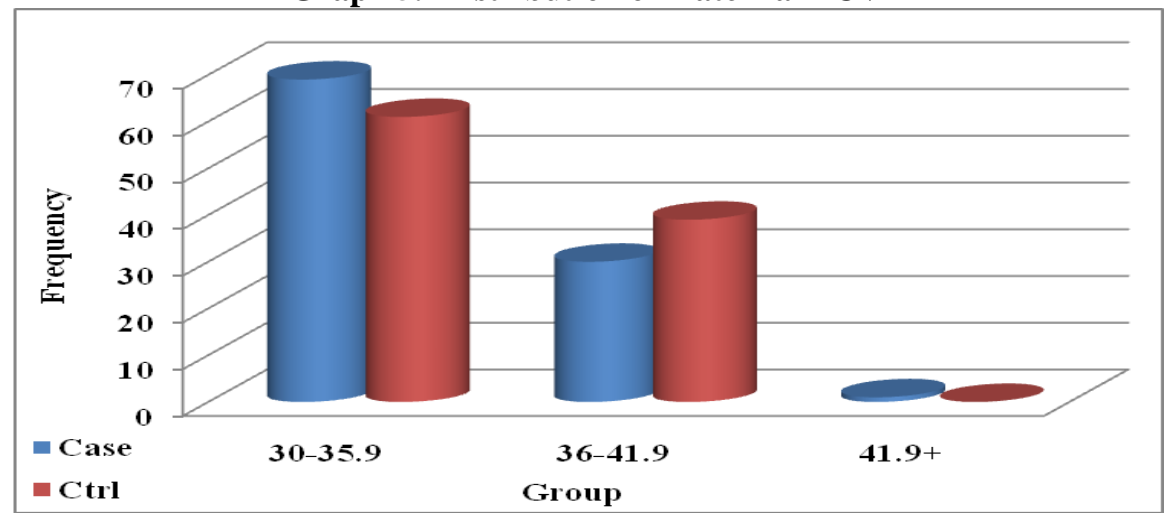

Both study and control groups are comparable in relation to maternal variables like age,parity,duration of amenorrhoea,maternal PCV.

Table 6. Neonatal PCV at 18 to 24 hrs of life

\begin{tabular}{|c|c|c|c|c|c|}
\hline \multirow{2}{*}{\multicolumn{2}{|c|}{ Variable }} & & \multicolumn{2}{|c|}{ GROUP } & \multirow[b]{2}{*}{ Total } \\
\hline & & & Case & Ctrl & \\
\hline \multirow{12}{*}{$\begin{array}{l}\text { NEOPCV } \\
\text { in } \%\end{array}$} & \multirow[t]{2}{*}{$42-45$} & Frequency & 0 & 33 & 33 \\
\hline & & $\%$ & $.0 \%$ & $33.0 \%$ & $16.5 \%$ \\
\hline & \multirow[t]{2}{*}{$45-50$} & Frequency & 0 & 67 & 67 \\
\hline & & $\%$ & $.0 \%$ & $67.0 \%$ & $33.5 \%$ \\
\hline & \multirow[t]{2}{*}{$50-55$} & Frequency & 29 & 0 & 29 \\
\hline & & $\%$ & $29.0 \%$ & $.0 \%$ & $14.5 \%$ \\
\hline & \multirow[t]{2}{*}{$55.1-60$} & Frequency & 58 & 0 & 58 \\
\hline & & $\%$ & $58.0 \%$ & $.0 \%$ & $29.0 \%$ \\
\hline & \multirow[t]{2}{*}{$60.1-65$} & Frequency & 12 & 0 & 12 \\
\hline & & $\%$ & $12.0 \%$ & $.0 \%$ & $6.0 \%$ \\
\hline & \multirow[t]{2}{*}{$65.1-70$} & Frequency & 1 & 0 & 1 \\
\hline & & $\%$ & $1.0 \%$ & $.0 \%$ & $.5 \%$ \\
\hline \multirow{2}{*}{\multicolumn{2}{|c|}{ Total }} & Frequency & 100 & 100 & 200 \\
\hline & & $\%$ & $100.0 \%$ & $100.0 \%$ & $100.0 \%$ \\
\hline
\end{tabular}

$\mathrm{P}=0.000$ (Significant)

The above table shows a maximum number of neonatal PCV in case group are in between $51.1 \%$ to $60 \%$, with mean of 55.5\%.Maximum neonatal PCV in control group are in between $45 \%$ to $50 \%$, with mean of $47.5 \%$.

\section{Graph 6. Neonatal PCV at 18 to 24 hrs of life}

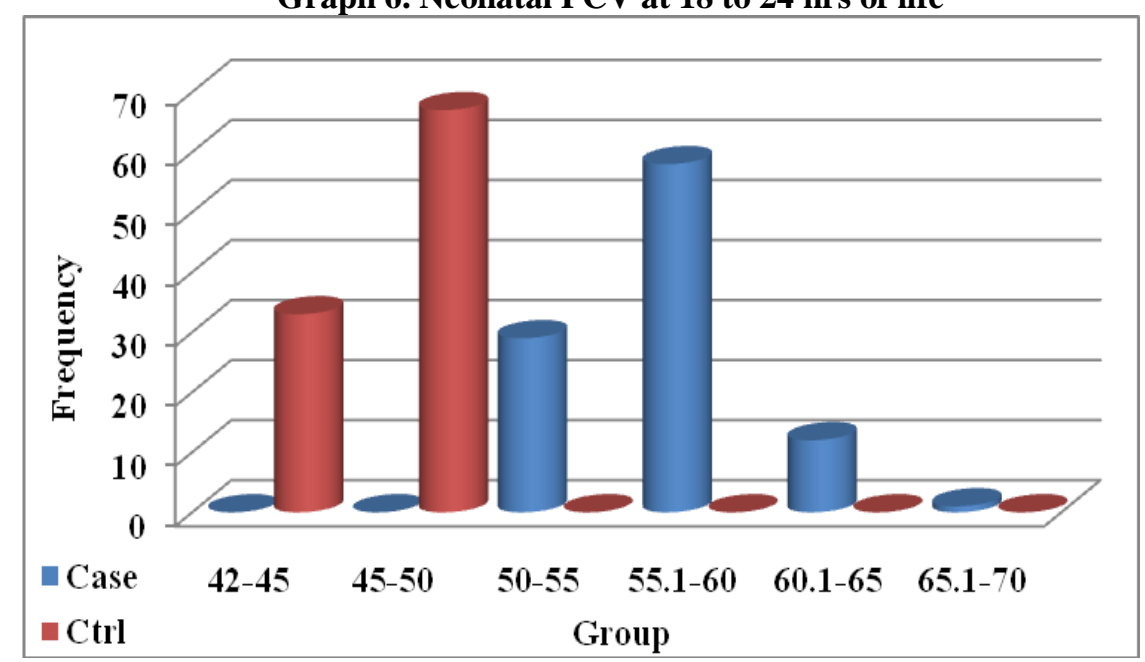

By this observation we can say that there is a significant raise of haematocrit in late clamped groups compaired to early clamped group. 
Table 7. Secondary outcomes

\begin{tabular}{|c|c|c|c|c|c|}
\hline \multirow{2}{*}{\multicolumn{2}{|c|}{ Variable }} & & \multicolumn{2}{|c|}{ GROUP } & \multirow[b]{2}{*}{ Total } \\
\hline & & & Case & Ctrl & \\
\hline \multirow[t]{6}{*}{ SECOUT } & \multirow[t]{2}{*}{ Nil } & Frequency & 57 & 65 & 122 \\
\hline & & $\%$ & $57.0 \%$ & $65.0 \%$ & $61.0 \%$ \\
\hline & \multirow{2}{*}{$\begin{array}{l}\text { Jaundice } \\
\text { (observation) }\end{array}$} & Frequency & 34 & 29 & 63 \\
\hline & & $\%$ & $34.0 \%$ & $29.0 \%$ & $31.5 \%$ \\
\hline & \multirow{2}{*}{$\begin{array}{l}\text { Jaun2 } \\
\text { (phototheraphy) }\end{array}$} & Frequency & 9 & 6 & 15 \\
\hline & & $\%$ & $9.0 \%$ & $6.0 \%$ & $7.5 \%$ \\
\hline \multirow{2}{*}{\multicolumn{2}{|c|}{ Total }} & Frequency & 100 & 100 & 200 \\
\hline & & $\%$ & $100.0 \%$ & $100.0 \%$ & $100.0 \%$ \\
\hline
\end{tabular}

$\mathrm{P}=0.467$ (not significant)

The above table shows,34 neonates of case group and 29 neonates of control group developed jaundice but not required phototheraphy.

9 neonates of case group needed phototheraphy and NICU admission,and 7 neonates of control group needed phototheraphy and NICU admission.

Graph 7. Neonates developing jaundice

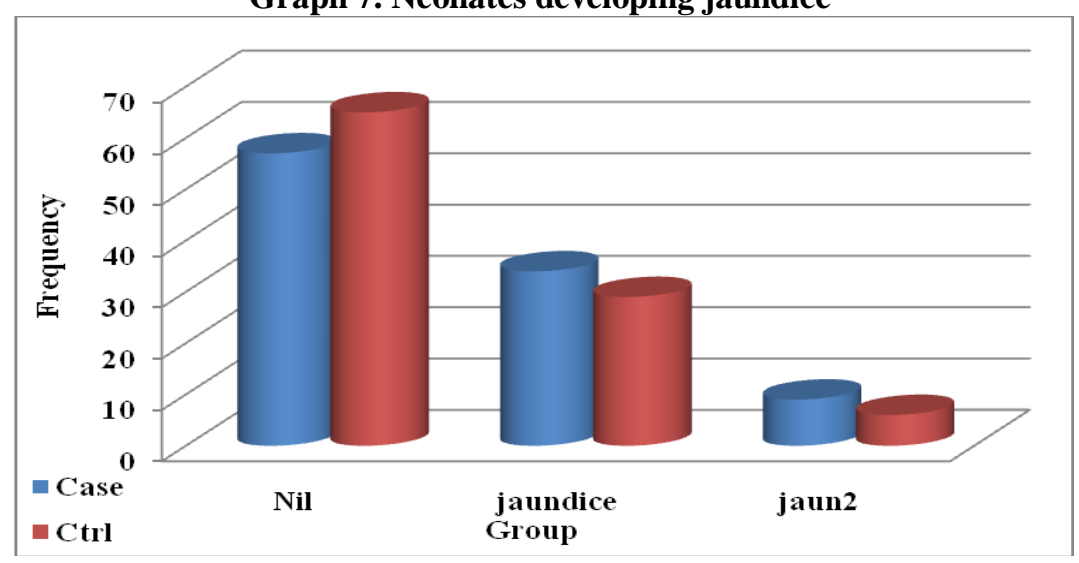

By this observation we can say that there is no statistical significant increase in risk of neonatal jaundice in late clamped group compaired to early clamped group.

Table 8. Follow up at 1 and half month

\begin{tabular}{|c|c|c|c|c|c|}
\hline \multirow{2}{*}{\multicolumn{2}{|c|}{ Variable }} & & \multicolumn{2}{|c|}{ GROUP } & \multirow[b]{2}{*}{ Total } \\
\hline & & & Case & Ctrl & \\
\hline \multirow{4}{*}{$\begin{array}{l}\text { FOLLOW } \\
\text { at one and } \\
\text { half } \\
\text { months. }\end{array}$} & \multirow[t]{2}{*}{ No } & Frequency & 89 & 88 & 177 \\
\hline & & $\%$ & $89.0 \%$ & $88.0 \%$ & $88.5 \%$ \\
\hline & \multirow[t]{2}{*}{ Yes } & frequency & 11 & 12 & 23 \\
\hline & & $\%$ & $11.0 \%$ & $12.0 \%$ & $11.5 \%$ \\
\hline \multirow{2}{*}{\multicolumn{2}{|c|}{ Total }} & Frequency & 100 & 100 & 200 \\
\hline & & $\%$ & $100.0 \%$ & $100.0 \%$ & $100.0 \%$ \\
\hline
\end{tabular}

11 in cases and 12 in Control Came for Followup. 


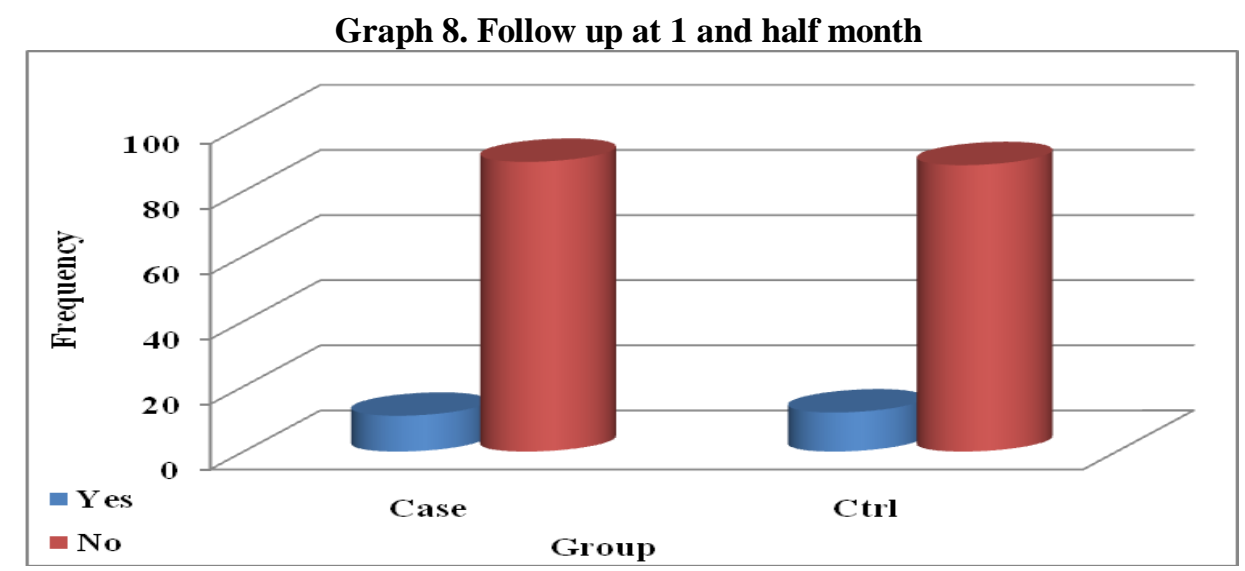

Table 9. Follow up(PCV) at one and half months

\begin{tabular}{|l|c|c|c|c|c|}
\hline \multirow{2}{*}{ Variable } & GROUP & No. of Babies & (Pcv\%) Mean & Std. Deviation & $\begin{array}{c}\text { Std. Error } \\
\text { Mean }\end{array}$ \\
\hline FOLLOWUP PCV & Case & 11 & 50.6364 & 2.54058 & .76601 \\
\cline { 2 - 6 } & Ctrl & 12 & 45.6667 & 1.23091 & .35533 \\
\hline
\end{tabular}

$\mathrm{P}=0.000$ (Significant)

Mean PCV in Cases $-50.6 \%$. Mean PCV in Control-45.5\% at 1 and half month, which shows there is clinically significant increase in haematocrit in delayed clamped group as compared to early clamped group at one and half months of life.

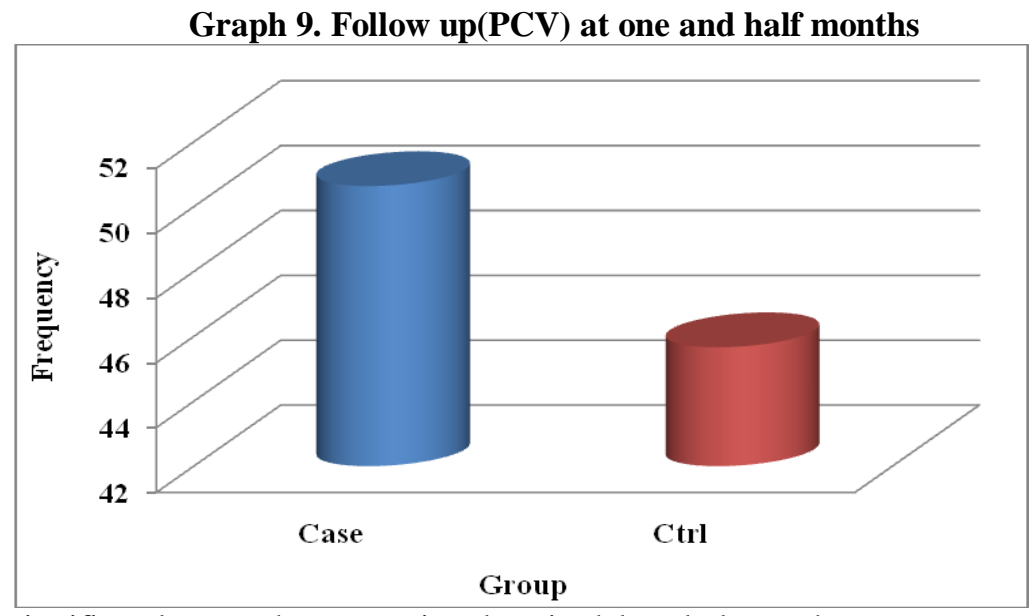

There is a significantly more haematocrit values in delayed clamped group compared to early clamped group during follow up at 1 and half month which is statistically significant.

Table 10. Neonatal birth weight and development of jaundice

\begin{tabular}{|c|c|c|}
\hline Bt.wt & Case -jaundice & Ctrl-Jaundice \\
\hline $2.5-3 \mathrm{kgs}$ & 19 & 20 \\
\hline $3.1-3.5 \mathrm{kgs}$ & 15 & 9 \\
\hline
\end{tabular}

$\mathrm{P}=0.787$ (Not significant) 


\section{Graph 10. Neonatal birth weight and development of jaundice}

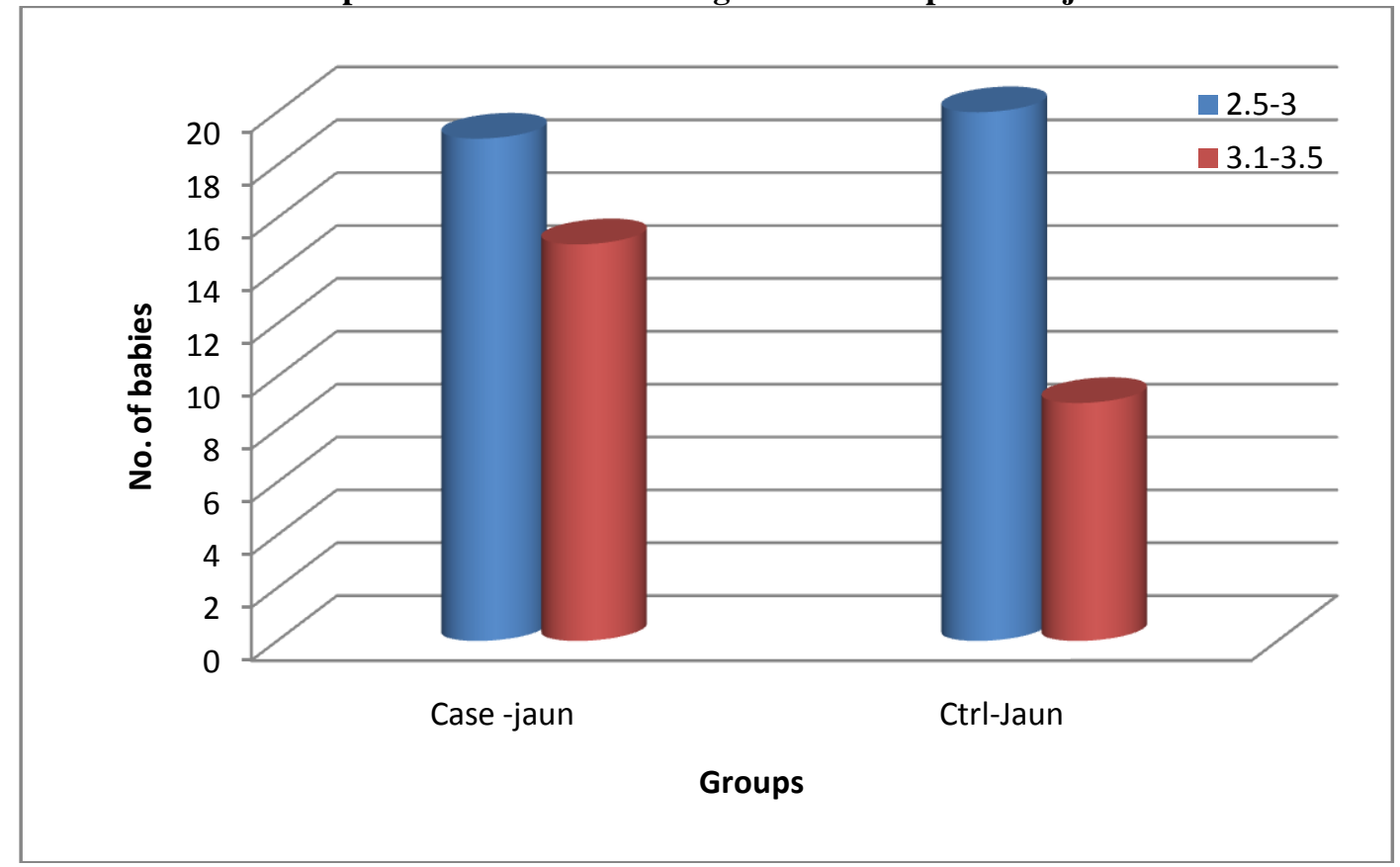

More no. of neonates developed jaundice who has a birth weight between 2.5 to $3 \mathrm{kgs}$.

Table 11. Neonatal birth weight and development of jaundice for which phototherapy was needed

\begin{tabular}{|c|c|c|}
\hline Bt.wt & Case -Phototherapy & Control- Phototherapy \\
\hline $2.5-3 \mathrm{kgs}$ & 4 & 4 \\
\hline $3.1-3.5 \mathrm{kgs}$ & 5 & 3 \\
\hline
\end{tabular}

$\mathrm{P}=0.706$ (Not significant)

Graph 11. Neonatal birth weight and development of jaundice for which phototherapy was needed

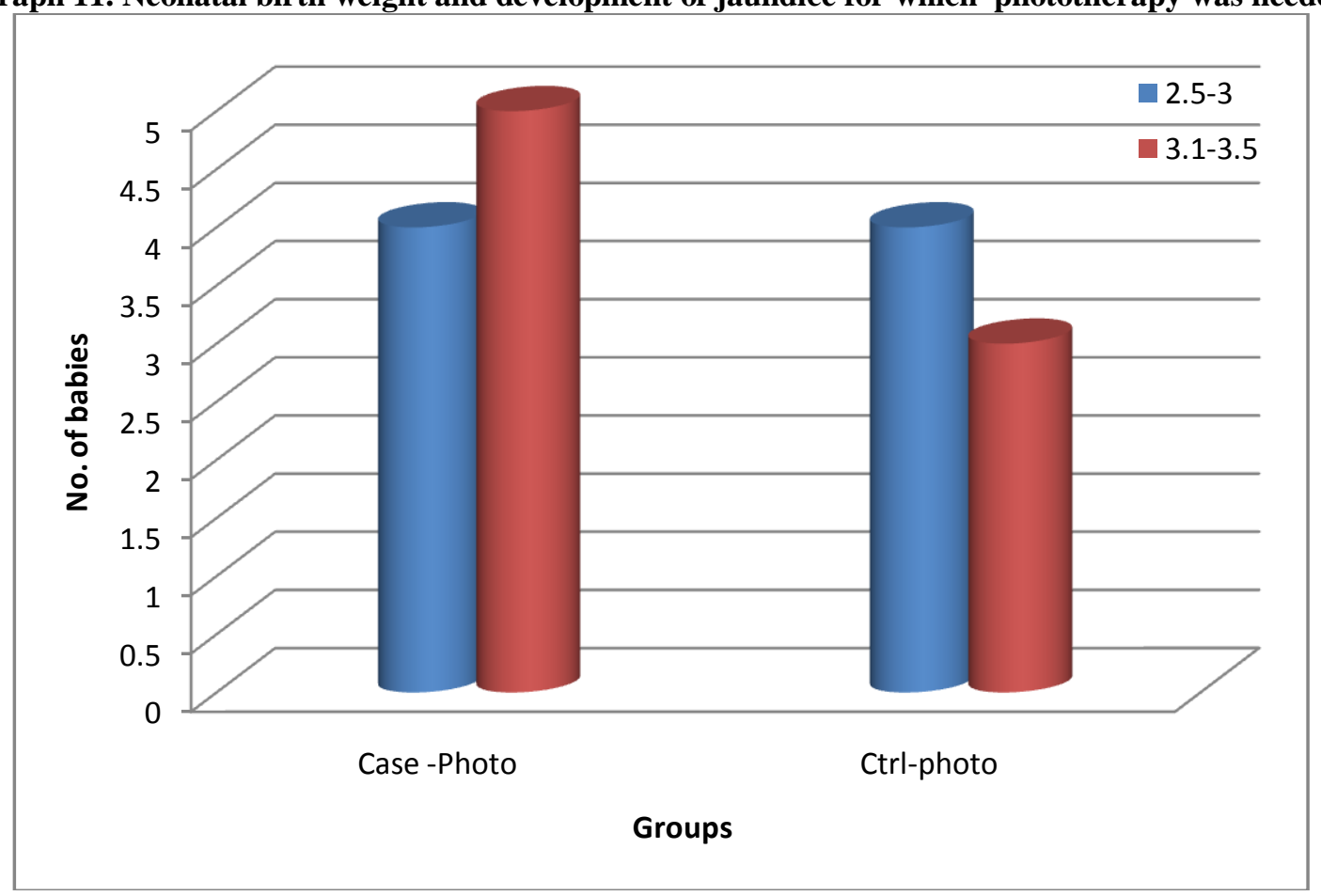


Table 12. Sex of the neonates and development of jaundice

\begin{tabular}{|c|c|c|}
\hline Variable & Male & Female \\
\hline Case & 28 & 6 \\
\hline Control & 18 & 11 \\
\hline
\end{tabular}

$\mathrm{P}=0.071$ (Not significant)

Graph 12. Sex of the neonates and development of jaundice

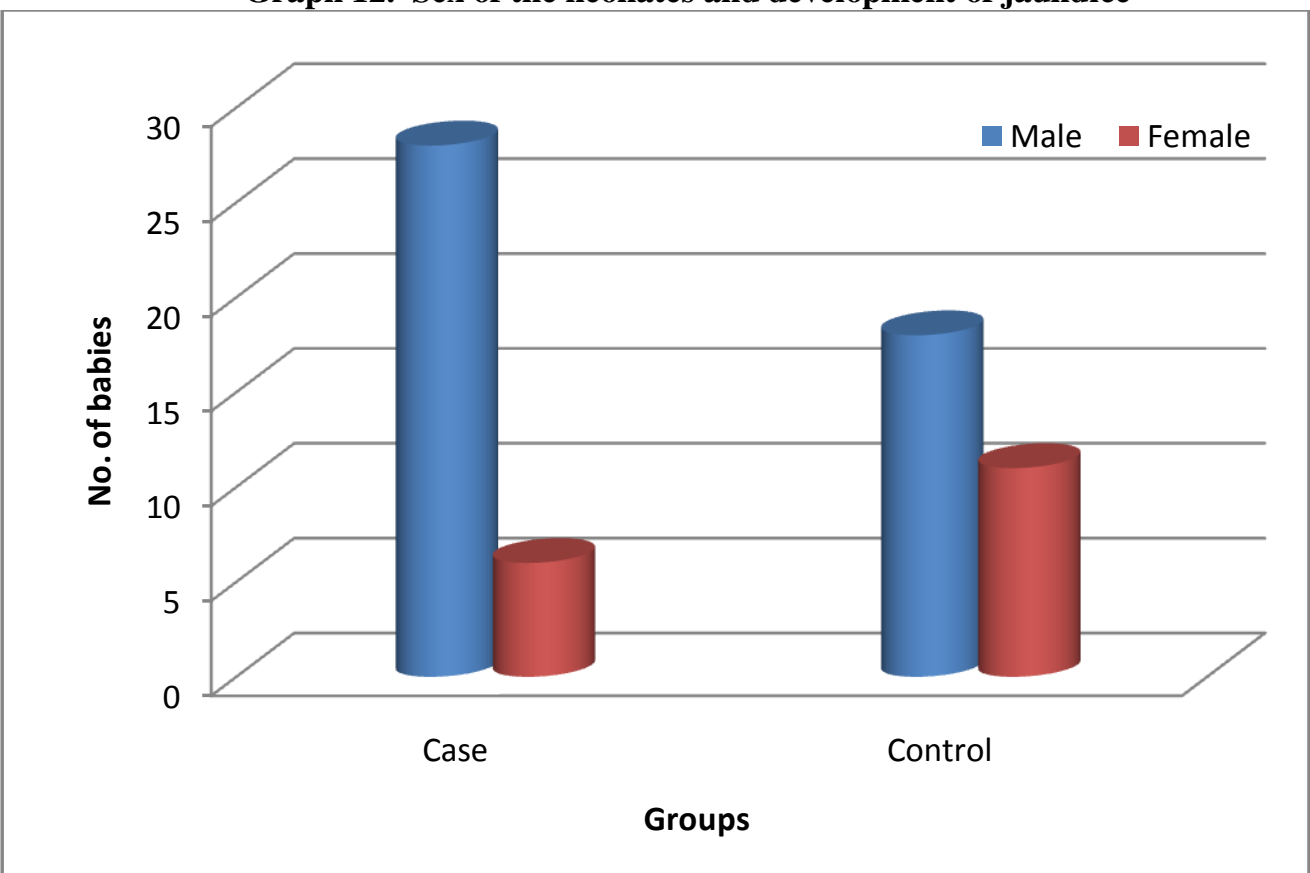

Comparatively more no. of male babies developed jaundice in both group. But not statistically significant.

\section{Discussion}

Our prospective randomized controlled study evaluated the potential placental transfusion effects on the newborn when cord is clamped after stoppage of pulsation in comparison to early cord clamping. This study was designed to demonstrate that in late cord clamping there is an increase in venous haematocrit which is within physiological ranges $(35 \%-65 \%)$

\section{Comparison with other studies}

\section{Comparison of age of women}

\begin{tabular}{|c|c|c|c|c|}
\hline \multirow{2}{*}{ Variables } & \multicolumn{2}{|c|}{ Present study (our study) } & \multicolumn{2}{c|}{ Ruber Grajeda Rafad perez in Guatemalan infants } \\
\cline { 2 - 5 } & Early & Late & Early & Late \\
\hline Age (mean) & $21-25 \mathrm{yrs}$ & $21-25 \mathrm{yrs}$ & $25.8 \pm 7$ years & $25.3 \pm 6.3 \mathrm{yrs}$ \\
\hline
\end{tabular}

The mean age group in our study in both early and late clamped group is 21-25 years.

And in the study done by Ruber Grajeda and others mean age in early clamped group is $25.8 \pm 7$ yrs and in late clamped group $25.3 \pm 6.3$ yrs, thus both study have same age group women.

\begin{tabular}{|c|c|c|c|c|}
\hline \multirow{2}{*}{ Variables } & \multicolumn{3}{|c|}{ our study } & \multicolumn{2}{c|}{$\begin{array}{c}\text { Ruber Grajeda Rafad perez in } \\
\text { Guatemalan infants }\end{array}$} \\
\cline { 2 - 5 } & Early & Late & Early & Late \\
\hline Birth weight & $25-3 \mathrm{kgs}$ & $2.5-3 \mathrm{kgs}$ & $3 \pm 0.4 \mathrm{kgs}$ & $3.2 \pm 0.5 \mathrm{kgs}$ \\
\hline
\end{tabular}

The mean birth weight of neonates in both early and late clamped group in our study is in between 2.5 $\mathrm{kg}$ to $3 \mathrm{kgs}$ and in the study done by Ruber Grajeda is others means birth weight in early clamped group is $3 \pm 0.4$ $\mathrm{kgs}$ in late clamped group is $3.2 \pm 0.5 \mathrm{kgs}$, which is almost same. 


\begin{tabular}{|c|c|c|c|c|c|c|c|c|c|c|}
\hline \multirow[t]{2}{*}{ Variables } & \multicolumn{2}{|c|}{ our study } & \multicolumn{2}{|c|}{$\begin{array}{c}\text { Ruber Grajeda } \\
\text { Rafad peles } \\
\text { Guatemalan } \\
\text { infants }\end{array}$} & \multicolumn{2}{|c|}{$\begin{array}{c}\text { Ola Anderson,Dan } \\
\text { Anderson in BMJ } \\
\mathbf{2 0 1 1}\end{array}$} & \multicolumn{2}{|c|}{$\begin{array}{l}\text { Jose M Ceriani } \\
\text { Cesuades MD }\end{array}$} & \multicolumn{2}{|c|}{ Jose Tantasean } \\
\hline & Early & Late & Early & Late & Early & Late & Early & Late & Early & Late \\
\hline $\begin{array}{l}\text { Neonatal } \\
\text { PCV at } 24 \\
\text { hrs of life } \\
\text { (mean) }\end{array}$ & $47.5 \%$ & $55.5 \%$ & $42 \%$ & $55 \%$ & $50 \%$ & $53 \%$ & $51.1 \%$ & $56.5 \%$ & $51 \%$ & $57 \%$ \\
\hline
\end{tabular}

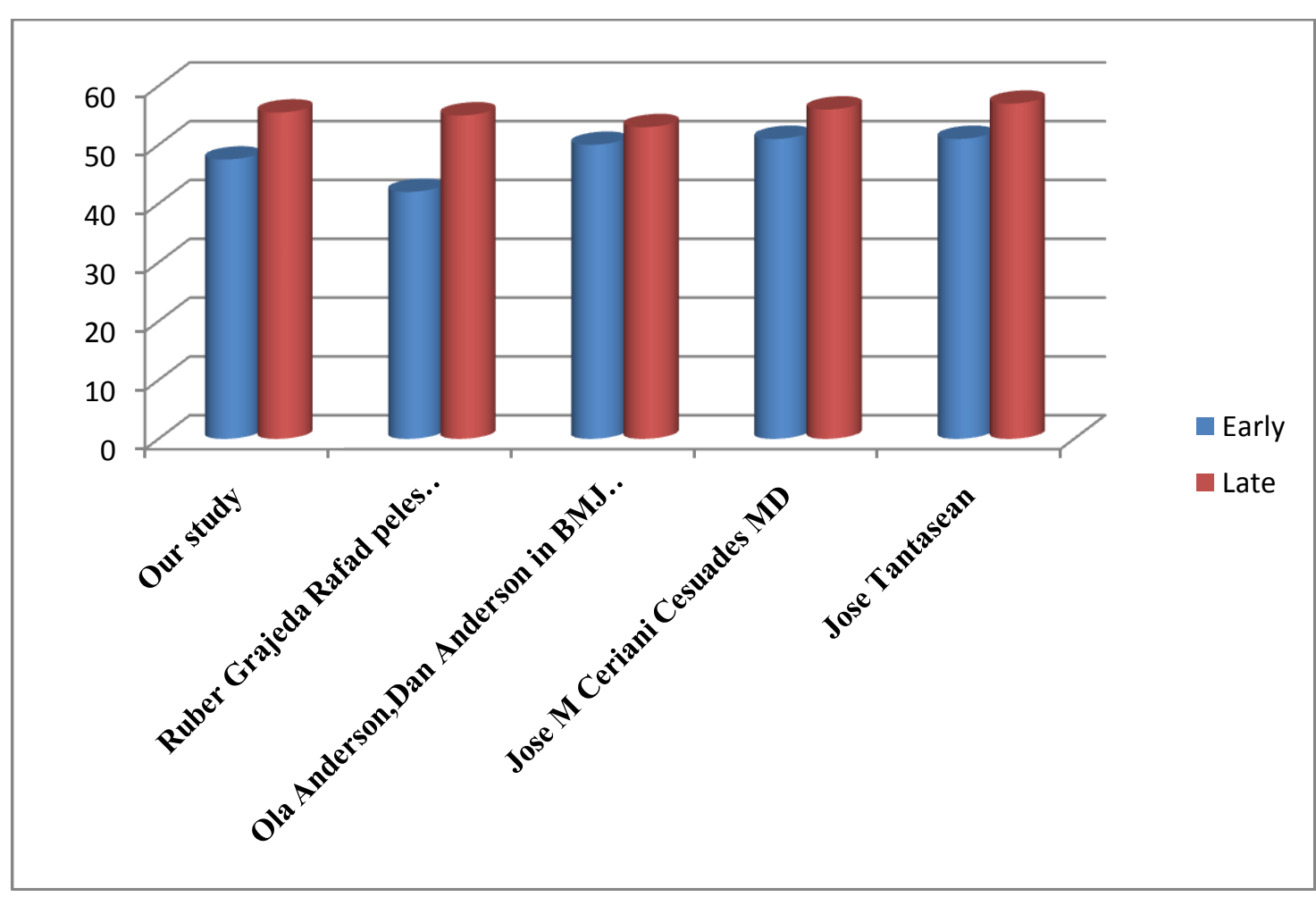
is $55.5 \%$.

In our study neonatal PCV at $24 \mathrm{hrs}$ of life in early clamped group is $47.5 \%$ and in late clamped group

And in study done by Ruber Grajeda and others the PCV in early clamped group is $42 \%$ and in late clamped group is $55 \%$, which is almost similar. And in the study done by Ola Anderson neonatal PCV in early clamped group is $50 \%$ and in late clamped group is $53 \%$, which is similar comparied to our study.In study done by Jose M Ceriani Cernades PCV in early clamped group is $51.5 \%$ and in late clamped group is $56.5 \%$, which is similar to our study. And in study done by Jose Tantalean PCV of neonates in early clamped group is $51 \%$ and in late clamped group is $57 \%$.

In all these studies the PCV of neonates in late clamped group is significantly more then the early clamped group, which correlates with our study.

Comparison of neonates developing jaundice

\begin{tabular}{|c|c|c|c|c|c|c|c|c|c|c|}
\hline Variables & \multicolumn{2}{|c|}{ Our study } & \multicolumn{2}{|c|}{$\begin{array}{c}\text { Ruber } \\
\text { Grajeda } \\
\text { Rufad Perez }\end{array}$} & $\begin{array}{c}\text { Ola Anderson } \\
\text { and Dan } \\
\text { Anderson }\end{array}$ & $\begin{array}{c}\text { Jose M Ceriani } \\
\text { Cernades }\end{array}$ & \multicolumn{2}{|c|}{ Jose Tantalean } \\
\cline { 2 - 11 } & Early & Late & Early & Late & Early & Late & Early & Late & Early & Late \\
\hline Jaundice & $29 \%$ & $34 \%$ & $12 \%$ & $25 \%$ & $4 \%$ & $7 \%$ & $4 \%$ & $13 \%$ & $5.9 \%$ & $14 \%$ \\
\hline
\end{tabular}




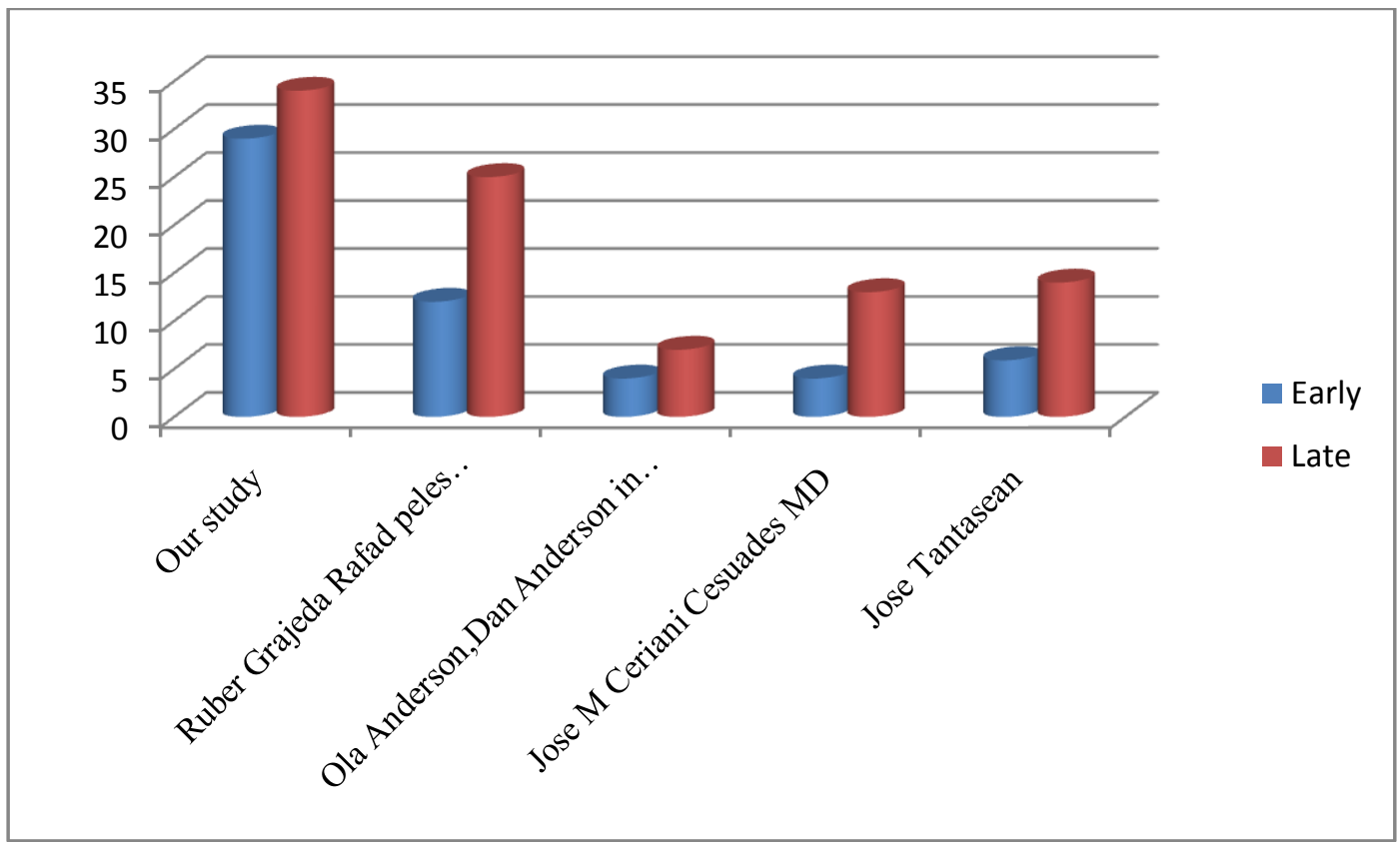

The development of jaundice in early clamped group in our study is $29 \%$ and late clamped group in our study is $29 \%$ and late clamped group is $34 \%$, where as the study done by Ruber Grajeda the development of jaundice in early clamp group is $12 \%$ and late clamped group is $25 \%$, and in study by Ola Anderson in early clamped group is $4 \%$ and in late clamped group is $7 \%$, and in study done by Jose M Ceriani Cernades development of jaundice in early clamped group is $4 \%$ and in late clamped group is $13 \%$, and in study done by Jose Tantalean development of jaundice in early clamped group is 5.9\% and in late clamped group is $14 \%$.

So development of jaundice in our group in both the group is more compaired to above mentioned studies it may be because of active management of labour with use of oxytocin in all our cases.

\begin{tabular}{|c|c|c|c|c|c|c|}
\hline \multirow{2}{*}{ Variables } & \multicolumn{2}{|c|}{ Our study } & \multicolumn{2}{c|}{$\begin{array}{c}\text { Ola Anderson Dan } \\
\text { Anderson }\end{array}$} & \multicolumn{2}{c|}{ Jose M Ceriani Cernades } \\
\cline { 2 - 7 } & Early & Late & Early & Late & Early & Late \\
\hline $\begin{array}{c}\text { NICU } \\
\text { admission }\end{array}$ & $7 \%$ & $9 \%$ & $2 \%$ & $1 \%$ & $4 \%$ & $8 \%$ \\
\hline
\end{tabular}

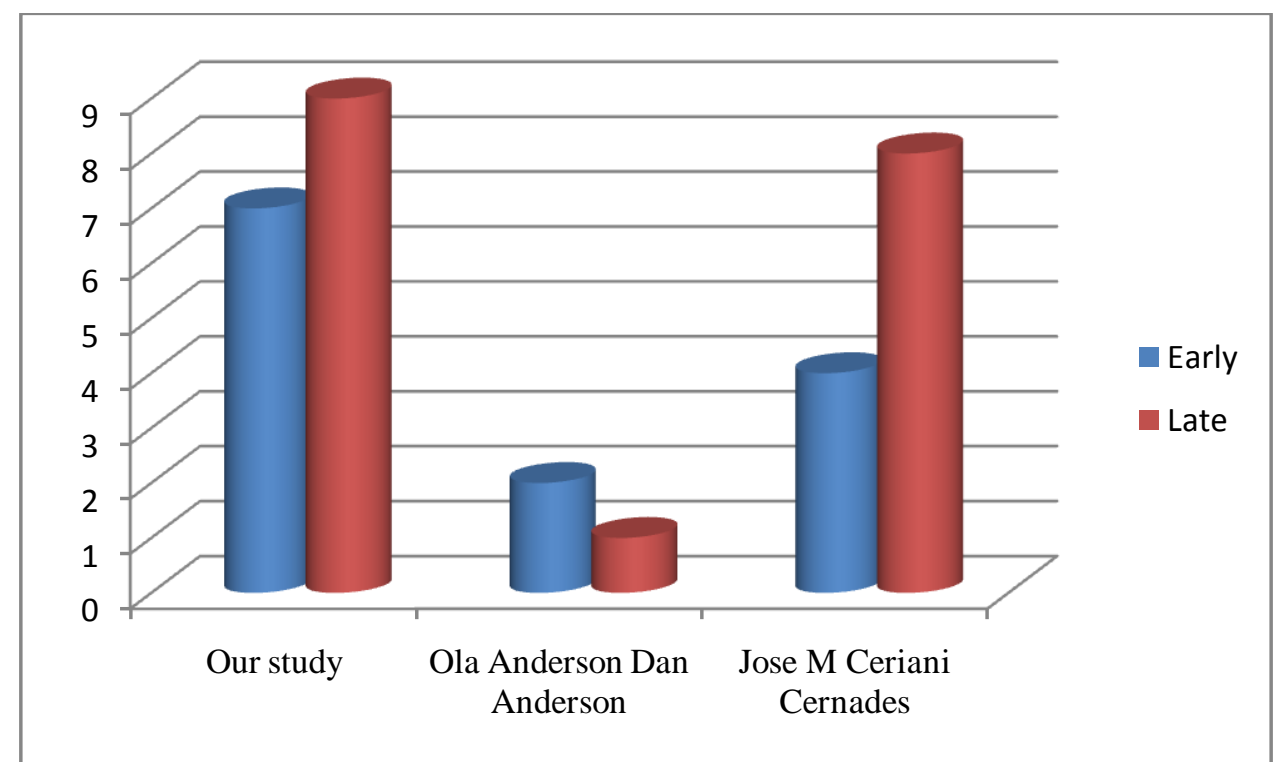

In our study the neonates requiring NICU admission for phototherapy in early clamped group is $7 \%$ and that of late clamped group is $9 \%$, whereas in study done by Ola Anderson the neonates requiring NICU 
admission for phototherapy in early clamped group is $2 \%$ and that of late clamped group is $1 \%$,and in study done by Jose M Ceriani Cernades neonates requiring jaundice in early clamped group is $4 \%$ and in late clamped group is $8 \%$, which shows a large number of babies in our study needed NICU admission in both group compared to study done by Ola Anderson and Jose M Ceriani Cernades.

Comparison of length of hospital stay

\begin{tabular}{|c|c|c|c|c|}
\hline \multirow{2}{*}{ Variables } & \multicolumn{2}{|c|}{ Our study } & \multicolumn{2}{c|}{ Jose M Ceriani Cernades } \\
\cline { 2 - 5 } & Early & Late & $3 \%$ (phototherapy) & $3.5 \%($ phototherapy) \\
\hline $\begin{array}{c}\text { Length of } \\
\text { hospital stay }\end{array}$ & $2 \%$ (normal) & $2 \%$ (normal) & \\
\hline
\end{tabular}

The length of hospital stay in both early and late clamped neonates in our study is $2 \%$ in neonates who not developed jaundice and is $4 \%$ in babies who developed jaundice and needed phototherapy and NICU admissions, and in study done by Jose M Cerianis Cernades the length of hospital stay in both early clamped neonates is $3 \%$ and late clamped neonates is $3.5 \%$ who developed jaundice, which is almost similar.

Our study is comparable to almost all studies like study done by Ruber Grajeda Rafad perez, Ola Anderson Dan Anderson,Jose M Ceriani Cernades,Jose Tantalean.

In our study number of neonates developing jaundice was more in both early and delayed clamped group in compared to other studies, and this increase in neonatal jaundice may be explained because more use of oxytocin during delivery. The neonatal admission was also more in our study because of increased incidence of neonatal jaundice in our study.

The rest of the parameters were almost same in our study as compared to other study.And haematocrit is more in followup at one and half months in delayed clamped grouped neonates in compaired to early clamped group.

\section{Conclusion}

Our study clearly indicates that late clamping is definitely helpful in increasing haematocrit of newborn and also haematocrit at one and half months. There is slight increase in neonatal jaundice which is not much significant. Hence according to our study it is advisable to advice late cord clamping for newborn babies.

\section{Summary}

The study was conducted in J.S.S.Hospital, Mysore from November 2010 to July 2012, on 200 newborns, in 100 newborns cord is clamped immediately after delivery and in 100 newborns cord is clamped when pulsations are stopped, and the venous blood of newborn is drawn within 24hours of life for measurement of haematocrit. And the neonates are followed at one and half months and again haematocrit of neonates are measured.

Our study included the following variables,

Age

Gravid

Duration of pregnancy

Maternal PCV

Neonatal PCV

Neonatal birth weight

Neonatal sex

Neonate birth weight and babies developing jaundice.

Neonatal birth weight and babies developing jaundice for which phototherapy was needed

Length of hospital stay

Follow up at $1 \frac{1 / 2}{2}$ months of life.

\begin{tabular}{|c|c|c|}
\hline Variables & Cases $(n=100)$ & Controls $(n=100)$ \\
\hline Age & $21-25$ years & $21-25 \mathrm{yrs}$ \\
\hline Gravid & Primi (58) & Primi (55) \\
\hline Duration of pregnancy & 37-39 weeks & 37-39 weeks \\
\hline Maternal PCV & $30-35.9 \%$ & $30-35.9 \%$ \\
\hline Neonatal PCV in 24 hrs of life & $55.5 \%$ & $47.5 \%$ \\
\hline Neonatal birth weight & $2.5-3 \mathrm{kgs}$ & $2.5-3 \mathrm{kgs}$ \\
\hline $\begin{array}{l}\text { Neonatal secondary outcome } \\
\text { Jaundice (observation) }\end{array}$ & $34 \%$ & $29 \%$ \\
\hline Phototherapy & $9 \%$ & $7 \%$ \\
\hline $\begin{array}{l}\text { Neonatal birth weight with babies developing } \\
\text { Jaundice (observation) }\end{array}$ & $2.5-3 \mathrm{kgs}$ & $2.5-3 \mathrm{kgs}$ \\
\hline Neonatal birth weight with babies developing & 3 to $3.5 \mathrm{kgs}$ & $2.5-3 \mathrm{kgs}$ \\
\hline
\end{tabular}




\section{The Effect of Timing of Cord Clamping On Neonatal Venous Haematocrite Values}

\begin{tabular}{|l|c|c|}
\hline Jaundice (phototherapy) & & \\
\hline Mean PCV for which babies developing jaundice & $55-60 \%$ & $46-50 \%$ \\
\hline Neonatal sex and development of jaundice & Male-28,Female-6 & Male-18,Female-11 \\
\hline Length of hospital stay & $\begin{array}{c}\text { days (without } \\
\text { jaundice) } \\
\text { days (with jaundice) }\end{array}$ & $\begin{array}{c}2 \text { days (without jaundice) } \\
4 \text { days (with jaundice) }\end{array}$ \\
\hline Follow up at 1 1/2 months (PCV) & $50.6 \%$ & $45.6 \%$ \\
\hline
\end{tabular}

Cases (delayed clamped group),control(early clamped group)

Maximum number of women were in the age group 21-25years in both the groups

And maximum women in both groups are primigravidas, 58\% were primigravidas in cases and 55\% were in control group.

Maximum number of women presented at gestational age 37-39\% in both the groups.

Maternal haematocrit in both the groups range from $30-35.9 \%$.

Mean neonatal haematocrit at 24 hours of life in delayed clamped neonates was $55.5 \%$, and in early clamped neonates was $47.5 \%$, by this its clear that there is a significant increase in neonatal haematocrit by delayed cord clamping.

Maximum neonates birth weight in both group were $2.5-3 \mathrm{kgs}$.

$34 \%$ neonates in delayed clamped group and $29 \%$ neonates in early clamped group developed jaundice but not needed phototherapy.

9\% neonates in delayed clamped group and $7 \%$ in early clamped group developed jaundice and who required phototherapy and NICU admission.

Maximum number of neonates who developed jaundice were in birth weight $2.5-3 \mathrm{kgs}$ in both groups.

Maximum number of neonates who developed jaundice are male babies, 28 neonates in delayed clamped group of total 34 neonates who developed jaundice, and 18 neonates in early clamped group of total 29 were male.

Length of hospital stay is 2 days in both the groups in neonates who not developed jaundice, and 4 day who developed jaundice.

11 neonates in delayed clamped group, and 12 neonates in early clamped group came for followup at one and half months. Mean haematocrit in delayed clamped neonates was $50.6 \%$ and that in early clamped group was $45.6 \%$, which demonstrates haematocrit in delayed clamped group is more than early clamped group at one and half months of life

\section{Bibilography}

[1]. Ramnik sood, Concise Book of Medical Laboratory Technology. $4^{\text {th }}$ edition 2006

[2]. Robin K, Ohis and Robert D, Christensen: Nelson Textbook of Paediatrics. 18th edition, 2008; 1997-1998.

[3]. Jose M Ceriani Cernades MD GUILERMO Carrali MD Liliana Pellegrim MD: official journal of the American Academy of Pediatrics. April 2006, Vol.117, No.4:PP. 2779-2786.

[4]. Gupta R, Ranji S: Effect of delayed cord clamping on iron stores in infants born to anaemic others; a randomized controlled trials: Indian Paediatr 2002 Feb;39(2):130-1355

[5]. Bhargava, Kumar R, Iyer PU, Ramji S, Kapani 5, Bhargava SK: Effect of maternal anaemia and iron depletion on fetal iron stores, birth weight and gestations. Acta Pediatr Scand 1989;78:321-322.

[6]. Hassan:Journal of American Medical Association 2007;297:1257-1258.

[7]. Hilary Butler. mothering: Delayed cord clamping, 1986, No.41.

[8]. R Grajeda, R Perez-Escamilla, K G Dewey: American Journal of Clinical Nutrition, 1997; vol 65: 425431

[9]. McDonald SJ, Middleton P: Effect of timing of cord clamping of term infants on maternal and neonatal outcome: Cochrane Database Syst Rev 16:2008; CD004074.

[10]. Hutton and Hassan AM Fam Physician evidence favour late cord clamping in infants. 2008 Jan;77 (2): 231 -232.

[11]. Cariani Cemades JM, Carroli G Pellegrini: Effect of timing of cord clamping on neonatal haematocrit. Vol 3 issue 3 of Research summaries for normal birth July 2006.

[12]. Cunnigham, Leveno, Bloom, Hareth, Rouse, Sponge: William's obstetrics - 23rd edition 2010; page no.397.

[13]. British medical journal.Umbilical cord clamping should be delayed,2010;341:c5441.

[14]. Ola Anderson,Lena Hellstrom-westas Dan Anderson Magnus Domellof.Effect of Delayed Versus Early umbilical cord clamping on neonatal outcomes and iron status at 4 month a randomized controlled trial BMJ,2011;Dol:10.1136/bmj.d7157.

[15]. Patrick Van Rheenen.Delayed cord clamping and improved infant outcomes.BMJ,2011;Dol:10.1136/bmj.d7127

[16]. David J R Hutchon. Personal view: Why do obstetricians and midwives still rush to clamp the cord?BMJ,2010;341:c5447Dol:10.1136/bmj.c5447.

[17]. Jose N Tolosa,Dong-Hyuk Park,David J.Eve, Stephenle, Cesariov. Borlongan,Paul R.Sanberg.Mankind first natural stem cell transplant. Journal of cellular molecular medicine,2010;Dol:10.1111/j.1582-4934.2010.

[18]. Periman JM, Wyllie J,Kattwinkel J, et al. Neonatal Rescusitation:2010 Internatal consensus on cardiovascular care science with Treatment Recommendations.Pediatrics.2010;126:e 1319-44.

[19]. Gustavo Pelligra.Pediatric Child Health.2010 December;15(10):640

[20]. Oh W, Carlo WA, Fanaroff AA, McDonald S, Donovan EF, Poole K, et al. Delayed cord clamping in extremely low birth weight infants - a pilot randomised controlled Trial. Pediatric Research 2002;51(4 Suppl):36.

[21]. Rabe H, Wacker A, Hulskamp G, Hornig-Franz I, Schulze-Everding A, Harms E, et al. A randomised controlled trial of delayed cord clamping in very low birth weight preterm infants. European Journal of Pediatrics 2000;159(10):775-7.

[22]. Ibrahim HM, Krouskop RW, Lewis DF, Dhanireddy R. Placental transfusion: umbilical cord clamping in preterm infants. Journal of Perinatology 2000;120:351-4. 
[23]. Strauss RG, Mock MM, Johnson K, Mock NI, Cress G, Knosp L, et al. Circulating RBC volume, measured with biotinylated RBCs, is superior to the het to document the hematologic effects of delayed versus immediate umbilical cord clamping in preterm neonates. Transfusion 2003;43:1168-72.

[24]. Aladangady N, McHugh S, Aitchison TC, Wardrop CA, Holland BM. Infants' blood volume in a controlled trial of placental transfusion at preterm delivery. Pediatrics 2006;117(1):93-8.

[25]. Baenziger O, Stolkin F, Keel M, von Siebenthal K, Fauchere JC, Das Kundu S, et al. The influence of the timing of cord clamping on postnatal cerebral oxygenation in preterm neonates: a randomized, controlled trial. Pediatrics 2007;119(3):455-9.

[26]. Hosono S, Mugishima H, Fujita H, Hosono A, Minato M, Okada T, et al. Umbilical cord milking reduces the need for red cell transfusions and improves neonatal adaptation in infants born at less than 29 weeks' gestation: a randomised controlled trial. Archives of Disease in Childhood. Fetal and Neonatal Edition 2008;93(1):F14-9.

[27]. Hosono S, Mugishima H, Yonezawa R, Fujita H, Makimoto M, Okada T, et al. The effects of umbilical cord milking on cardiopulmonary adaptation in preterm infants. Journal of Maternal-Fetal and Neonatal Medicine 2008;21(Suppl 1):45.

[28]. Kugelman A, Borenstein-Levin L, Riskin A, Chistyakov I, Ohel G, Gonen R, et al. Immediate versus delayed umbilical cord clamping in premature neonates born $<35$ weeks: a prospective, randomized, controlled study. American Journal of Perinatology 2007;24(5):307-15.

[29]. Kugelman A, Borenstein-Levin L, Kessel A, Riskin A, Toubi E, Bader D. Immunologic and infectious consequences of immediate versus delayed umbilical cord clamping in premature infants: A prospective, randomized, controlled study. Journal of Perinatal Medicine 2009;37(3):281-7.

[30]. Mercer JS, McGrath MM, Hensman A, Silver H, Oh W. Immediate and delayed cord clamping in infants born between 24 and 32 weeks: a pilot randomized controlled trial. Journal of Perinatology 2003;23:466-72.

[31]. Mercer JS, Vohr BR, Oh W. Delayed cord clamping in very preterm infants reduces the incidence of intraventricular hemorrhage (IVH) and late onset sepsis (LOS) [abstract]. Pediatric Academic Societies Annual Meeting; 2005 May 14-17; Washington DC, USA. 2005:Abstract no: 2618 .

[32]. Mercer JS, Vohr BR, McGrath MM, Padbury JF, Wallach M, Oh W. Delayed cord clamping in very preterm infants reduces the incidence of intraventricular hemorrhage and late-onset sepsis: a randomized, controlled trial. Pediatrics 2006;117(4):1235-42.

[33]. Rabe H. Effects of a slight delay in cord clamping time versus milking the cord in preterm infants. Current Controlled Trials (www.controlled-trials.com) (accessed 21 June 2007) 2007.

[34]. Sekhavat L, Tabatabaii A. Immediate and delayed cord clamping in infants born between 26 and 34 weeks. Journal of MaternalFetal and Neonatal Medicine 2008;21(Suppl 1):181-2.

[35]. Strauss RG, Mock DM, Johnson KJ, Cress GA, Burmeister LF, Zimmerman MB, et al. A randomized clinical trial comparing immediate versus delayed clamping of the umbilical cord in preterm infants: short-term clinical and laboratory endpoints. Transfusion 2008;48(4):658-65.

[36]. Ultee CA, van der Deure J, Swart J, Lasham C, van Baar AL. Delayed cord clamping in preterm infants delivered at 3436 weeks' gestation: a randomised controlled trial. Archives of Disease in Childhood. Fetal and Neonatal Edition 2008;93(1):F20-3.

[37]. Brune T, Garritsen H, Witteler R, Schlake A, Wüllenweber J, Louwen F, et al. Autologous placental blood transfusion for the therapy of anemic neonates. Biology of the Neonate 2002;81:236-43 